\title{
PALEOHISTOLOGY AND THE STUDY OF HUMAN REMAINS: PAST, PRESENT AND FUTURE APPROACHES
}

\author{
Sandra Assis ${ }^{1}$, Ana Luísa Santos ${ }^{1}$ y Anne Keenleyside ${ }^{2}$ \\ ${ }^{I}$ CIAS - Research Centre for Anthropology and Health. Department of Life Sciences. University of Coimbra. Portugal \\ ${ }^{2}$ Department of Anthropology. Trent University. Peterborough. Ontario. Canada
}

KEYWORDS microscopy; dry bone remains; multiple approaches

\begin{abstract}
The invention of the microscope revolutionized the course of human knowledge. This instrument changed the face of science and of previous beliefs, expanded the horizons of knowledge, and challenged philosophical and scientific thought, especially in the field of natural sciences and medicine. In the domain of bioarchaeology, the introduction of histological techniques was important; not only to identify body tissues and to diagnose diseases in mummified remains,
\end{abstract}

but also to understand bone and teeth microstructure, and associated patterns of response to environmental constraints. In this paper a critical review of the major contributions of histology to the growing body of knowledge in paleopathology and bioarchaeology will be presented, focusing on the current multiple applications of microscopy, its limitations, and its future challenges. Rev Arg Antrop Biol 18(2), 2016. doi:10.17139/raab.2016.0018.02.02

PALABRAS CLAVE microscopía, restos humanos, múltiples enfoques

RESUMEN La invención del microscopio ha revolucionado el curso del conocimiento humano. Este instrumento cambió la "cara" de la ciencia y de las creencias anteriores, amplió los horizontes del conocimiento y retó al pensamiento filosófico y científico, especialmente en el campo de las ciencias naturales y la medicina. En el dominio de la bioarqueología, la introducción de técnicas histológicas fue determinante, no sólo para identificar los tejidos del cuerpo y diagnosticar enfermedades en restos momificados, sino también para

Four centuries have passed since the invention of the composite microscope. With this fascinating instrument the inner face of nature, once closed off to both intuition and direct observation, was revealed to the human eye (Mayr, 1982; Wilson, 1995; Mazzarello, 1999). The microscope's technical capabilities dramatically changed human concepts about the world, with substantial epistemological, metaphysical, and methodological implications to science (Wilson, 1995). By revealing layer after layer of very small articulated structures, the microscope gave sense to the idea of a non-occult interpretation of natural phenomena, leading to a truly remarkable "recalibration of human knowledge" (Wilson, 1995: 41). In agreement with Wilson (1995), the discovery of such a parallel microcosm offered metaphysicians the challenge to reconcile the ubiquity of life with contemporary anthropocentric views. Additionally, it revolutionized philosophical thought, shaking the foundations of previous beliefs (Mayr, 1982), and raising questions about the concepts of order and chaos, realism and the unrealistic world, comprender la microestructura y dinámica de los huesos y los dientes, y los patrones asociados de respuesta a las restricciones ambientales. En este trabajo se presenta una revisión crítica de las principales contribuciones de la histología al creciente cuerpo de conocimientos de la paleopatología y la bioarqueología, con énfasis en las actuales aplicaciones de la microscopía, sus limitaciones y los desafíos para el futuro. Rev Arg Antrop Biol 18(2), 2016. doi:10.17139/ raab.2016.0018.02.02

and the boundaries of human perception, as well as about the role of "instrumentally mediated knowledge" in the improvement of science (Wilson, 1995: 71).

The discovery of an entire world of microscopic living forms comprising algae, bacteria, protozoa, fungi, and viruses introduced new doubts about their origin, continuity, and possible relationship with human diseases (Mayr, 1982). In fact, it is almost impossible to talk about the findings of Gerhard Hansen (1841-1912, Norway), Robert Koch (1843-1919, Germany) and Louis Pasteur (1822-1895, France) without refer-

Funding: This research was developed within Fundação para a Ciência e Tecnologia funded $\mathrm{PhD}$ project (Grant numbers: $\mathrm{SFRH} / \mathrm{BD} / 36739 / 2007)$.

*Correspondence to: Sandra Assis. CIAS-Centro de Investigação em Antropologia e Saúde. Department of Life Sciences, Faculty of Sciences and Technology. University of Coimbra. Calçada Martins de Freitas. 3000-456 Coimbra. Portugal. Email: sandraassis78@gmail.com

Recibido 20 Diciembre 2014; aceptado 10 Marzo 2015

doi:10.17139/raab.2016.0018.02.02 
ring to the value of the microscope (Kato, 1973; Ben-Menahem, 2009; Merrill, 2010). In the medical domain, the use of the microscope allowed the development of innovative methods for anatomical dissection, as complex body systems could be separated into smaller components -the tissues and the cells (Hogg, 1854; Mayr, 2004). Besides gross anatomy, physicians were now able to examine the physiology of organs and the interaction of cells (Mayr, 2004). For instance, we can mention the first descriptions of bone histology published by Antonie van Leeuwenhoek on November 20, 1720: "It is impossible for those, who have not seen this with their own eyes, to conceive the prodigious number of small vessels, of which the cortical part of the bone consists; which in some places lies no thicker upon the spongy part of the bone, than a thick hair of a man's head (...)" (p. 92). Microscopy has also made an important contribution to disease diagnosis (Hays, 2009; Merrill, 2010). Focusing on this issue, Hogg stated that "the smallest portion of a diseased structure, placed under a microscope, will tell more in one minute to the experienced eye than could be ascertained by many days' examination of the gross masses of disease in the ordinary method" (1854: vi). The usefulness of microcopy surpassed the frontiers of biology and medicine, being incorporated by other sciences. This was the case for paleopathology. In the bioarchaeological domain, the application of tissue microscopy is, by itself, deeply embedded in the history of paleopathology as a modern science (Aufderheide and Rodríguez-Martín, 1998). Presently, the microscope continues to be fundamental in the fields of biological and forensic anthropology.

This paper aims to review the role of paleohistology in the progression of the anthropological body of knowledge focusing on (1) the first incursions of microscopy into disease diagnosis; (2) the current applications of paleohistology to the study of past remains; and (3) the limits and future challenges of histology on bioarchaeological studies.

\section{Paleohistology, disease diagnosis, and the emergence of new histological techniques}

The first application of histology to the study of ancient pathological remains -the scope of paleopathology- can be traced back to the nineteenth century. With respect to the analysis of mummified remains, this technique was pioneered by the Czech physician J. N. Czermak in 1879 to describe a case of arteriosclerosis in an Egyptian mummy (Aufderheide and Rodríguez-Martín, 1998; Aufderheide, 2003; Denton, 2008). In the beginning of the twentieth century, Sir Armand Ruffer, a professor of Bacteriology in Cairo (who is also considered the father of paleopathology), developed revolutionary methods for rehydrating mummified tissues for histological inspection (Sandison, 1967; Aufderheide and Rodríguez-Martín, 1998; Aufderheide, 2003; Denton, 2008). In order to restore the flexibility of tissues, Ruffer's method consisted in embedding sectioned material in several cycles of alkaline salts (sodium carbonate) mixed with alcohol for two to three days, followed by baths in pure reagents (alcohol, chloroform or paraffin) (Moodie, 1921). Through this innovative procedure, several pathological conditions were identified in mummified and bone remains, such as arterial diseases, diffuse anthracosis of lungs, kidney abscesses, spondylitis deformans of vertebrae, among others (Moodie, 1921). In his paper entitled "Histological studies on Egyptian mummies," presented at L'Institut Égyptien in 1911, Ruffer emphasized the importance of the systematic use of histology as a complement to the macroscopic observation of pathological changes (Moodie, 1921). Almost at the same time the eminent British pathologist S. G. Shattock studied histological sections of an aorta of an Egyptian pharaoh (Lovell, 2000). Since this early beginning, the contribution of histology to the analysis of disease in mummified bodies has been considerable (e.g. Sandinson, 1955; Post and Daniels, 1969; Armitage and CluttonBrock, 1981; Weinstein et al., 1981; Walker et al., 1987; Zimmerman et al., 1998; Ciranni et al., 1999). This growing interest was improved by new techniques for the preparation of mummified tissue (e.g. Graf, 1949; Sandinson, 1955; Turner and Holtom, 1981; Hess et al., 1998; Aufderheide, 2003; Mekota and Vermehren, 2005).

Histological examination was also applied by Roy L. Moodie to the study of bone lesions on nonhuman fossil remains (Moodie, 1918a and 
$1918 b$ ), for example, a fracture in a rib of a reptile from the Permian of Texas (Moodie, 1918b); a hemangioma on two caudal vertebrae of an Apatosaurus from the Comanchian (Moodie, 1918a and 1918b); and a case of osteoperiostitis observed on a humerus of a Mosasaur from the Cretaceous (Moodie, 1918a and 1918b). Apart from applying this new diagnostic technique, Moodie also introduced the concept of paleohistology in 1926 (Garland, 1993). Nevertheless, it was not until 1949 that a proper definition was proposed by Wilhelm Graf, who described paleohistology as "the examination of microscopic sections of ancient human beings and the recognizing of tissues and cells in such sections" (1949:236). With regard to the study of archaeological human bone, the first histological analysis was undertaken by the American pathologist Theopfil Mitchell Prudden in 1891 (Garland, 1993). Prudden used microscopy to confirm a possible case of syphilis observed in two adult tibiae exhumed from the prehistoric site of Animas River, Colorado, whose microstructure revealed chronic periostitis and osteomyelitis. Another historical reference concerning the application of histology to skeletonized remains is attributed to Carl Magnus Fürst who diagnosed, in 1920, a case of periostitis ossificans in the tibia of King Magnus of Sweden (thirteenth century AD) (Graf, 1949). In 1927, M. Weber developed a new microscopic technique to distinguish inflammatory bone lesions linked to presumed syphilitic cases (Graf, 1949; Schultz, 1997). In spite of Weber's efforts to standardize diagnosis, little attention was paid to his work (Schultz, 1997). A year later, H. U. Williams described an experimental method for the study of osteoporotic bones that consisted in embedding fragile bones in celloidin and then decalcifying them in an acid solution (Graf, 1949). Focusing on the preservation of mummified and dry bone remains, Graf (1949) performed a comparative study on three Egyptian mummies and fifteen Swedish skeletons from different chronological periods, concluding that there were no parallels between the chronology and the microscopic preservation of remains (an assertion that is still valid today, see e.g. Stout and Teitelbaum, 1976; Schmidt-Schultz and Schultz, 2007). No pathological indicators were recorded by the author. Besides comparative histomorphology,
Graf also tested other methods. Regarding the preparation of dry bone specimens, he adopted the classical histopathological procedures used by clinicians that consisted in bone decalcification (nitric acid), paraffin-embedding and staining techniques (Graf, 1949).

Despite all the medical improvements associated with the use of light and polarized microscopy, as well as in techniques for the decalcification, paraffin wax embedding, and handgrinding of human bone, the histological analysis of archaeological bone and teeth remained underdeveloped until the mid-1990s (Garland, 1993). Two main reasons may explain this lack of interest: firstly, the emphasis placed, in bioanthropological studies during the first half of the twentieth century, for example, on the description of skull morphology and subsequent "racial" classification (Garland, 1993; Armelagos and Van Gerven, 2003); and, secondly, some technical limitations dictated by the nature of the samples. The physical properties of archaeological bone and teeth fall between those of fresh and fossil origin: they do not possess the elasticity that characterizes living tissues, nor the hardness of fossil remains; a fact that causes considerable difficulties during bone sectioning (Turner-Walker and Mays, 2008). The situation began to change in the 1950s with the introduction of plastic embedding techniques for the preparation of thin sections and new microscope devices (Herrmann, 1993; Turner-Walker and Mays, 2008). Shortly afterwards, the feasibility of plastic embedding media started to be investigated, with researchers trying to find the quickest and most advantageous method to produce bone samples (e.g. Arnold and Jee, 1954; Woodruff and Norris, 1955; Pugh and Savchuck, 1958). Focusing on the preparation of thin undecalcified bone sections, Frost published, in 1958, the guidelines for an innovative method characterized by its simplicity, cheapness, rapidity, and dependability. Instead of being fixed, embedded, dehydrated, and heated -as in the previous methods-, bone was simply ground on both sides using abrasive paper on a plate of glass gently moistened with water (Frost, 1958). In 1968, Frost and Hoyte published two distinct papers concerning the use of staining-labelling techniques (in vivo) to evaluate the rates of bone formation and resorption in undecalcified bone samples. 
Although these innovations were first used in the field of medicine, they were rapidly adapted to the study of ancient remains. In 1969, the results of one of the first applications of the electron microscope to the analysis of pathological tissues from Egyptian and Peruvian mummies were presented by Macadam and Sandison (1969). Criticizing the pioneering methods of decalcification of ancient human bone, Stout and Teitelbaum (1976) proposed a new method using plastic embedding substances (methyl methacrylate). According to these authors, this technique provided excellent preservation of bone microstructure, allowing for the diagnosis of many systematic diseases and deficiencies (Stout and Teitelbaum, 1976). Two years later, Pawlicki (1978) described an alternative method combining grinding and staining techniques for the preparation of fossil bone for light and transmission electron microscopy. In 1988, a rapid method for producing stained undecalcified bone sections was presented by Emmanual (1988). A similar work based on methyl methacrylate embedding and staining protocols was published by Sterchi and Eurell (1989). Two years later, Maat (1991) used a scanning electron microscope to compare the ultrastructure of both normal and pathological red blood cells with pseudopathological structures. The same technology was applied by Wakely et al. (1991) to the study of rib lesions. In 1995, Abou-Arab and coauthors published a technical note concerning the importance of staining in the study of secondary osteons. Caropreso et al. (2000) made available a simple method based on resin embedding (epoxy resin), cutting and mounting procedures that could be applied to both modern and archaeological remains. A year later, a revised and modified version of Frost's rapid manual method was proposed by Maat and coauthors (2001). In the same year, an innovative method for the morphological study of fungi and bacteria contaminating ancient human bone that combined resin embedding (Impex "threephase" polyester resin) and staining techniques was presented by Dore et al. (2001). In the meantime, several studies were conducted to test the feasibility of the available methods for the study of dry bone samples (e.g. Beauchesne and Saunders, 2006; Martiniaková et al., 2006). Recently, a new method for embedding, saw- ing, grinding, and staining was proposed by De Boer et al. (2012 and 2013a) in order to study undecalcified archaeological bone samples, especially when lesions were present. In addition to the improvements in the preparation of samples, other sophisticated microscope techniques were introduced to the study of archaeological remains - namely, the atomic force microscope (Thalhammer et al., 2001), the epifluorescence microscope, microscopic computerized tomography, and the confocal laser scanning microscope (Kuhn et al., 2007; Rühli et al., 2007; Maggiano et al., 2009; Šefčáková et al., 2001).

\section{Paleohistological analysis: examples of its application}

A review of the bioarchaeological literature permits the identification of several studies that base their methodological framework on histological techniques. In the following pages, a short overview of the multiple applications of histology will be provided.

\section{Differentiation between human, nonhu- man remains, and other structures}

Histology is a useful tool to distinguish between human and nonhuman bone remains, especially when bone is fragmentary (e.g. Harsányi, 1993; Hillier and Bell, 2007; Croker et al., 2009; Greenlee and Dunnell, 2009; Mulhern and Ubelaker, 2012). This differentiation is possible because humans have a scattered distribution of cortical osteons, as well as of primary bone types, when compared with other mature mammals that have a plexiform pattern (e.g. Pfeiffer, 2000; Cuijpers, 2006; Pfeiffer, 2006; Cattaneo et al., 2009) and show osteon banding (Mulhern and Ubelaker, 2001; 2012). Apart from human and nonhuman primates (i.e. chimpanzees), which share a similar bone microstructure and age-related changes (Mulhern and Ubelaker, 2003), the distinguishing features of bone histomorphometry also allow for the taxonomic classification of zooarchaeological remains (e.g. Barnes et al., 2000; Miles, 2001; Horni, 2002; Dittmann, 2003; Dittmann et al., 2006; Martiniaková et al., 2007; Paral et al., 2007). Histology has also played a role in the identification of strange bodies re- 
covered from human skeletal remains, such as renal and biliary calculi (e.g. Morris and Rodgers, 1989; Sanchez and Etxeberria, 1991), calcified tissues and organisms (e.g. Perry et al., 2008; Quintelier, 2009), fossilized body fluids and faecal deposits (Maat, 1991; Blondiaux and Charlier, 2008; Shillito et al., 2011), and parasites and contaminating substances (e.g. Oh et al., 2010).

\section{Taphonomic processes and identification of burned remains}

When bone is exposed to the burial environment it may experience structural changes induced by physical, chemical and biological agents (Stout, 1978; Garland, 1993; Bell at al., 1996; Schultz, 1997; Collins, 2002; Jans, 2008; Turner-Walker and Jans, 2008; Reiche et al., 2010). The study of postmortem alterations is important to differentiate decomposition phenomena from normal physiological processes and disease lesions (e.g. Stout, 1978; Lynne, 1990; Grupe and Dreses-Werringloer, 1993; Turner-Walker and Jans, 2008). In this area, microscopy has been used to evaluate the integrity of bone microstructure in different environmental contexts (e.g. Stout, 1978; Hermann, 1986; Hanson and Buikstra, 1987; Garland, 1993; Hedges et al., 1995; Bell et al., 1996; Nicholson, 1998; Nielsen-Marsh and Hedges, 2000; Roberts et al., 2002; Jans et al., 2004; Guarino et al., 2006; Schmidt-Schultz and Schultz, 2007; Tersigni, 2007; Monsalve et al., 2008; Jans, 2008; Turner-Walker, 2008; TurnerWalker and Jans, 2008; Bell, 2012; Hollund et al., 2012). In zooarchaeological studies it also contributes to understanding the diagenetic processes that affect buried bones and teeth (Haynes et al., 2002; Stutz, 2002). Microscopic methods are also of great value for examining pathological conditions and estimating age at death of cremated remains (e.g. Holden et al., 1995; Schultz, 1997; Hanson and Cain, 2007; Squires et al., 2011).

\section{Estimation of age at death in skeletonized human remains}

Several histological methods have been developed to estimate age at death in both ancient and modern bone and dental remains. Bone growth, modeling, and remodeling are responsible for a mature cortex with particular features that can be quantified using histomorphometric analysis (Schultz, 1997; Pfeiffer, 2000; Robling and Stout, 2008; Stout and Crowder, 2012); that is, the quantitative study that consists in counting or measuring tissue components: cells or extracellular constituents or both (Boivin and Meunier, 1993: 137). Histological indicators of age are based on the grade of remodeling of osteons and their respective quantification in adult cortical bone (Simmons, 1985; Frost, 1987; Stout and Paine, 1992; Mulhern and Ubelaker, 2003; Streeter, 2012). Different skeletal elements have been considered in these studies, namely, ribs and clavicle (e.g. Stout and Paine, 1992; Stout et al., 1996; Crowder and Rosella, 2007; Kim et al., 2007; Pavón et al., 2010; Cho and Stout, 2011), long bones (e.g. Kerley, 1965; Singh and Gunberg, 1970; Kerley and Ubelaker, 1978; Pfeiffer, 1980; Stout and Gehlert, 1982; Frost, 1987; Stout and Stanley, 1991; Wallin et al., 1994; Ericksen, 1991 and 1997; Ericksen and Stix, 1991; Lynnerup et al., 2006; Maat et al., 2006b; Chan et al., 2007; Robling and Stout, 2008; De Donno et al., 2009; Han et al., 2009; Villa and Lynnerup, 2010), and ilium (e.g. Boel et al., 2007). The reliability of using weight-bearing bones, as well as the effect of intrinsic (sex and population variability) and extrinsic (adequate bone sampling) factors on age at death estimation, has also been discussed in the literature (e.g. Aiello and Molleson, 1993; Drusini, 1996; Iwaniec et al., 1998; Macho et al., 2005; Paine and Brenton, 2006; Robling and Stout, 2008; Henning and Cooper, 2011). Dental histological techniques have been developed on the basis of the study of secondary dentin formation, cementum annulation (e.g. Charles et al., 1986; Wittwer-Backofen et al., 2004; Maat et al., 2006a; Roksandic et al. 2009), striae of Retzius in enamel and daily cross striations (e.g. FitzGerald and Saunders, 2005; Martin et al., 2008), and root dentine translucency (e.g. Chandler and Fyfe, 1997). These methods have also been applied to the study of faunal remains (e.g. Beasley et al., 1992; Burke and Castanet, 1995; Wendy, 1998; Dirks et al., 2002). With regard to the cementum annulation technique, some publications question its reliability in the 
estimation of age at death in human remains (e.g. Miller et al., 1988; Renz and Radlanski, 2006).

\section{Ontogeny, phylogeny, and the skeletal response to biomechanical stress}

During the individual's lifetime, the skeleton has the capacity to adapt to biomechanical stress, increasing bone mass when activity increases or reducing bone tissue as a result of inactivity (Schultz, 1997; Pearson and Lieberman, 2004; Peck and Stout, 2007). Through histomorphometric analysis it is possible to infer strain levels and bone dynamics within populations or among human groups not only of different chronologies and geographic provenance, but also with different modes of subsistence (i.e. hunter-gatherers vs. agriculturalists) (e.g. Martin and Armelagos, 1985; Martin et al., 1987; Mulhern, 2000; Cho et al., 2006; Drapeau and Streeter, 2006). Histology also provides insights into the dynamics of bone growth and remodeling over the course of human ontogeny and evolution (e.g. Martin and Armelagos, 1979; Oyen et al., 1979; Abbott et al., 1996; Gosman and Ketcham, 2009). Furthermore, it allows for the development of standards for comparison with other nonhuman primates (e.g. Schaffler and Burr, 1984; Havill, 2003; Mulhern and Ubelaker, 2003). A similar contribution is made by the histological study of dentition (e.g. Molnar et al., 1981; Hildebolt et al., 1986, Mann et al., 1991; Anemone et al., 1996; Hillson and Bond, 1997).

\section{Mummy studies}

The analysis of mummified tissues was one of the first applications of histology to the study of ancient remains. Nowadays it continues to fascinate researchers in a variety of subjects that range from the simple identification of soft tissues (e.g. Post and Daniels, 1969; Walker et al., 1987; Shin et al., 2003; Mekota et al., 2005; Kim et al., 200) to the study of abnormal lesions and taphonomic changes (e.g. Brothwell et al., 1969; Bellard and Cortés, 1991; Ciranni et al., 1999; Ciranni and Fornaciari, 2004; Bianucci et al., 2008; Aufderheide, 2011).

\section{Bone paleopathology}

The long partnership between paleopathology and histology is clear from the literature, and it seems to hold much promise for the improvement of disease diagnosis. Nevertheless, the application of histological techniques to the study of dry bone remains seems to be residual in comparison with other technical approaches. In a systematic review of published literature in English, De Boer and coauthors (2013) found that few studies $(\mathrm{n}=57)$ have used histology as a paleopathological tool for differential diagnosis. Similar results were obtained by Assis (2013) in a literature review of articles written in English and French. Of a total of 5872 reference papers identified, only 94 focused on the paleohistological analysis of dry bone conditions (Assis, 2013). In most of the papers considered, histology was used as an auxiliary diagnostic tool, and not as a primary source for paleopathological evidence, mainly in the study of metabolic conditions, $34 \%$ or (32/94) (e.g. Stuart-Macadam, 1987; Bell and Jones, 1991; Aaron et al., 1992; Brickley and Ives, 2006; Brickley et al., 2007); benign and malignant tumors, $27 \%$ or $(25 / 94)$ (e.g. Eshed et al., 2002; Luna et al., 2008); and specific and non-specific infectious diseases, $23 \%$ or $(22 / 94)$ (e.g. Wakely et al., 1991; Von Hunnius et al., 2006; Weston, 2009). The lowest values were obtained in the analysis of combined pathologies $(5.3 \%)$ and bone trauma (4.3\%) (e.g. Kuhn et al., 2007; Rühli et al., 2007). The low specificity of some bone histomorphometric features (Weston, 2009; Van der Merwe et al., 2010), in addition to the invasive nature of most histological techniques (Bell and Piper, 2000; Ortner, 2003; Turner-Walker and Mays, 2008; Pfeiffer and Pinto, 2012), and the high level of scientific proficiency needed to interpret bone morphology at the microscopic level (Bell and Piper, 2000; Schultz, 2012) are the factors most frequently pinpointed to justify the reduced application of paleohistology as a diagnostic technique in paleopathology.

\section{Tooth alterations and bone cut marks}

Histological techniques have been applied to the analysis of tooth remains to make inferences about diet, behavior, and the impact of 
physiological stress on an individual's development. Dental microwear texture is studied in order to assess and compare dietary habits and seasonal changes in food resources among fossil hominins (e.g. Puech and Albertini, 1984; Lalueza et al., 1996; Ungar et al., 2006; Estebaranz et al., 2009), modern humans (e.g. Bullington, 1991; Teaford and Lytle, 1996; Schmidt, 2001; Mahoney, 2006; Patrick, 2006; Mahoney, 2007; Hogue and Melsheimer, 2008; Ma and Teaford, 2010), and nonhuman primates (e.g. Ryan, 1979; Gordon, 1982; Teaford and Runestad, 1992; Teaford et al., 1996; Nystrom et al., 2004; Scott et al., 2006). Certain patterns of microwear also reveal information about behavioral or "cultural" practices linked to the use of teeth as a third hand (e.g. Fox and Frayer, 1997; Ungar and Spencer, 1999; Minozzi et al., 2003; Lozano et al., 2008). Microscopic examination of linear enamel defects, such as Wilson bands, is also an important tool for understanding the physiological mechanisms responsible for growth disruptions during dental development (e.g. Rose, 1977; Rose et al., 1978; Marks and Rose, 1985; Goodman and Rose, 1990; King et al., 2005; Witzel et al., 2008).

Distinct microscopic techniques, such as scanning electron microscopy, have also been employed in the study of cut marks in human and nonhuman bone remains. These techniques are important to obtain evidence of hacking trauma and dismemberment in past populations and forensic contexts (Hutchinson, 1996; Ubelaker, 1998; Cox and Bell, 1999; Haverkort and Lubell, 1999; Bartelink et al., 2001; Tucker et al., 2001; Alunni-Perret et al., 2005); traces of defleshing in hominin fossil remains (e.g. White, 1986); and marks of butchering on faunal remains and their role in understanding the evolution of hominin handedness (e.g. Shipman and Rose, 1983; Bromage and Boyde, 1984; Bello and Soligo, 2008; Pickering and Hensley-Marschand, 2008). Cutmark micromorphology is also considered in the study of surgical or ritual bone incisions, such as trephinations, and their differentiation from taphonomic changes (e.g. Stevens and Wakely, 1993; Fabbri et al., 2012).

\section{Forensic anthropology}

As in past population studies, there is a con- siderable body of knowledge in the literature concerning the use of microscopy in forensic research. In commingled, fragmented, and burned bone or teeth remains, histological analysis may be useful to distinguish human from nonhuman remains (e.g. Cattaneo et al., 1999, 2009; Hillier and Bell, 2007). Furthermore, histology can be pivotal to determine the presence of bone or teeth in remains thought not to be of skeletal origin and vice versa (Ubelaker, 1998). In the particular case of cremated remains recovered from civil or criminal contexts, the use of microscopy can also help in the identification of non-bone material, as well as in the evaluation of particle morphology to assess age at death and associated constraints (Ubelaker, 1998). The microscopic identification of bone inclusions, such as desiccated insect parts, may provide clues about time since death or postmortem events (Ubelaker, 1998). Other possible applications concern the study of taphonomic changes (e.g. Bell et al., 1996), the assessment of age-at-death estimation (e.g. Maat et al., 2006b; Crowder and Rosella, 2007; Kim et al., 2007; Han et al., 2009), and trauma analysis (e.g. Bartelink et al., 2001; Alunni-Perret et al., 2005). In the scope of trauma investigation, the microscope plays a key role in: (1) differentiating trauma lesions from postmortem phenomena and developmental defects; (2) classifying the origin of trauma signs; and (3) identifying the nature of bone inclusions (for a more comprehensive review see Ubelaker, 1998).

\section{Paleontological studies}

Since the pioneering works of Roy Moodie, the application of paleohistological techniques continues to be fundamental to the analysis of nonhuman fossil remains. In addition to the classic transmitted light approach (brightfield or polarization), other methodologies are currently being used to examine fossil material (e.g. bone, teeth, ossified tendons, and eggshells) and to explore questions regarding the physiology, ontogeny, pathology, functional anatomy, and behavior of extinct vertebrates (Lamm, 2007). Of the abovementioned issues, life history patterns, evolutionary mechanisms, and intra- and inter-skeletal variation in growth, aging, and maturation are the features most commonly ana- 
lyzed in dinosaur taxa (e.g. Padian et al., 2001; Sander et al., 2004; Griebeler et al., 2013; Lee and O'Connor, 2013; Stein et al., 2013; Cullen et al., 2014).

\section{Paleohistology: current limitations and future challenges}

The contribution that the microscope has made to the development of science is enormous and difficult to express or quantify in numbers. Presently, cells, microorganisms, molecules, and nanoparticles are regarded as acquired evidence and used freely in the scientific discourse. The microscope changed the face of science and continues to be fundamental to the development of human knowledge. Year after year, new more sophisticated microscopes are being developed for use not only in biological and medical studies, but also in geology, paleontology, engineering, and physics. In medicine, histopathological analysis is crucial for the characterization of lesions and subsequent differential diagnosis. Nevertheless, the use of histological techniques in the study of past remains continues to be non-systematic. One of the common limitations attributed to paleohistology is its invasive and apparently destructive nature (Grupe and Garland, 1993; Ortner, 2003). Many museum curators and osteologists show an understandable reluctance to damage or allow the destruction of skeletonized remains in order to obtain samples (Turner-Walker and Mays, 2008). Bell and Piper (2000) explain this generalized feeling as the result of a misinterpretation of the meaning of the words "invasive" and "destructive". In many museums' sampling protocols, invasive analysis is used as a synonym for destructive handling, which is not completely true because a definitive sampling section can be preserved and archived indefinitely (Bell and Piper, 2000). Highlighting the role of histological collections, Spatola and coauthors (2012) have recently published a work describing the potential of using one of the largest bone slide collections in the world (with more than 10,000 slides of stained and undecalcified bone and joint specimens), housed at the Anatomical Division of the National Museum of Health and Medicine (NMHM) at the Armed Forces Institute of Pathology (AFIP) in Washington, DC, for research in paleopathology, bioarchaeology, and forensic science. Similar histological collections are curated at European universities and museums, for example, the Collection of the Department of Legal Medicine at the University of Vienna, in Austria, and the Collection of the Department of Pathology at the University of Göttingen in Germany (Schultz, 2012). According to Pfeiffer (2000), the progress of paleohistology is dependent on a change in the curatorial rules. Before denying access to skeletal collections, curators and researchers should be aware that the preparation of thin sections involves the transformation of material rather than its destruction (Pfeiffer, 2000). Sampling bones showing slight postmortem damage and/or small bone elements such as ribs, metacarpals or metatarsals is regarded as a solution to expedite lab work and reduce the degree of disruption of curated material (Pfeiffer, 2000). However, this solution may impose some constraints on the research design since it limits the spectrum of analysis. The presence of postmortem damage at macroscopic level may eventually pose an additional problem. Nevertheless, some studies have shown that, despite the diagenetic changes, a considerable amount of information can be gathered from histological analysis (Bell and Piper, 2000). To compensate for bone sectioning, Schultz (2012) proposes the use of a true-to-life cast or a plaster complement to replace the removed bone pieces. This procedure was used by Wapler et al. (2004) after the extraction of skull samples that presented cribra orbitalia. In that case, the sample gaps were filled with pieces of tightly adjusted plaster (Wapler et al., 2004).

Another drawback concerns the highly timeconsuming nature of histological techniques, which require expensive and sophisticated supplies (Schultz, 2012). This generalization is not entirely true because there are simple methods, like those published by Frost (1958) and Maat et al. (2001), that researchers can easily reproduce. The selection of a particular method is, of course, not random and depends on extrinsic factors (design and goals of the research) as well as on intrinsic ones (preservation of bone samples). Whenever bone samples are small or belong to fragile skeletonized pieces, the use of more timeconsuming techniques in order to guarantee high quality thin-sections is preferred (Schultz, 2012). 
The last and perhaps one of the greatest obstacles to paleohistological analysis is the researchers' lack of training. This limitation has been substantially discussed with regard to the reliable examination of paleopathological specimens (Bell and Piper, 2000; Pfeiffer and Pinto, 2012; Schultz, 2012), as well as in relation to the application of distinct methods for bone, teeth, and mummified tissue analysis. For instance, in a comparative study of seven methods for age-at-death assessment, Baccino and coauthors found that the histological "osteon" technique is more vulnerable to the experience of the observers, when compared with other approaches, such as the dental Lamendin method, concluding that the training and experience of the researchers is pivotal to reduce bias and inaccurate analysis. A deep understanding of the typical mosaic patterns found in normal and pathological cortical and trabecular bone (and in other preserved body tissues) throughout life could certainly make the interpretation of dry bone remains easier (Heuck, 1993).

The development of less invasive techniques is helping to reduce the main limitations frequently attributed to the histological study of skeletal remains. The synchrotron radiation $\mathrm{X}$-ray microtomography, which is characterized by limiting the degree of direct contact with bones, is being applied to the study of fossil remains (e.g. Tafforeau et al., 2006; Anné et al., 2014; Sanchéz et al., 2014). For example, Sanchez and colleagues (2012) have used phase-contrast synchrotron microtomography to provide new 3D insights into the submicronscale histology of fossil and recent bones. With this analytic approach, it was possible to see numerous bone features, such as vascular spaces and bone cell lacunae and canaliculi housing the dendritic processes of the osteocytes in some extant fossils. Other embedded bone features imperceptible to the conventional micro-CT scan (e.g. growth arrest lines, resorption surfaces, and extrinsic fibers) were also revealed through 3D synchrotron analysis (Sanchez et al., 2012). In spite of being non-invasive, recent studies have reported bone and teeth color changes caused by exposure to synchrotron radiation. This is more frequent in diagenetic bones and it affects their mineral content (Richards et al., 2012). These observations indicate that, to some extent, the synchrotron may cause some degree of physical damage (Richards et al., 2012). Another disadvantage of synchrotron microtomography is imposed by its size and the complexity of the infrastructure required to accommodate all the equipment. The use of circularly polarized microscopy (CPLM) may also greatly contribute to a better understanding of bone arrangement at a histological level. For instance, Goldman and colleagues (2008) have successfully applied circularly polarized light microscopy (CPLM) to study the pattern of collagen fiber orientation and its relation to biomechanical forces in a modern sample of mid-shaft human femurs. The portable confocal scanning light microscope (CSLM) constitutes another promising technique. As a non-destructive and portable technique, it has the advantage of not requiring sample preparation and it can be transported to the place where the subjects of study are stored (Bromage et al., 2005). This innovative technique has been used, for example, in the study of early hominin skeletal remains, such as the molar teeth of Australopithecus africanus and Paranthropus robustus (Lacruz et al., 2006).

In the future, a more frequent and systematic application of such techniques as portable confocal scanning light microscope (CSLM), circularly polarized light microscopy (CPLM) or even synchrotron radiation $\mathrm{X}$-ray microtomography will possibly overcome some of the current limitations identified in the study of past remains, which may lead to a more extensive application of histology in bioarchaeology and allied disciplines.

\section{Acknowledgments}

We gratefully acknowledge the editor and two anonymous reviewers for their helpful comments that strengthened the manuscript.

\section{Literature cited}

Aaron J, Rogers J, Kanis J. 1992. Paleohistology of Paget's disease in two medieval skeletons. Am J Phys Anthropol 89:325-331. doi:10.1002/ajpa.1330890306

Abbott S, Trinkaus E, Burr D. 1996. Dynamic bone remodelling in later Pleistocene fossil hominids. Am J Phys Anthropol 99:585-601. doi:10.1002/(SICI)10968644(199604)99:4<585::AID-AJPA5>3.0.CO;2-T

Abou-Arab M, Thomsen J, Frohlich B, Lynnerup N. 1995. Technical note:histological staining of secondary os- 
teons. Am J Phys Anthropol 98:391-394. doi:10.1002/ ajpa.1330980311

Aiello L, Molleson T. 1993. Are microscopic ageing techniques more accurate than macroscopic ageing techniques? J Arch Sci 20:689-704. doi:10.1006/ jasc. 1993.1043

Alunni-Perret V, Muller-Bolla M, Laugier J, Lupi-Pegurier L, Bertrand M, Staccini P, Bolla M, Quatrehomme G. 2005. Scanning electron microscopy analysis of experimental bone hacking trauma. J Forensic Sci 50:796801. doi:10.1520/JFS2003213

Lee A. H., O’Connor PM. 2013 Bone histology confirms determinate growth and small body size in the noasaurid theropod Masiakasaurus knopfleri. J Verteb Paleont 33 865-876. doi:10.1080/02724634.2013.743898

Anemone R, Moonet M, Siegel M. 1996. Longitudinal study of dental development in chimpanzees of known chronological age:implications for understanding the age at death of Plio-Pleistocene hominids. Am J Phys Anthropol 99:119-133. doi:10.1002/(SICI)10968644(199601)99:1<119::AID-AJPA7>3.0.CO;2-W

Anné J, Edwards NP, Wogelius RA, Tumarkin-Deratzian A, Sellers W, van Veelen A, Bergmann U, Sokaras D, Alonso-Mori R, Ignatyev K, Egerton V, Manning P. 2014. Synchrotron imaging reveals bone healing and remodelling strategies in extinct and extant vertebrates. J R Soc Interface 11:20140277. doi:10.1098/rsif.2014.0277

Armelagos G, Van Gerven D. 2003. A century of skeletal biology and paleopathology:contrasts contradictions and conflicts. Am Anthropol 105:53-64. doi:10.1525/ aa.2003.105.1.53

Armitage P, Clutton-Brock J. 1981. A radiological and histological investigation into the mummification of cats from Ancient Egypt. J Arch Sci 8:185-196. doi:10.1016/0305-4403(81)90023-6

Arnold J, Jee W. 1954. Embedding and sectioning undecalcified bone and its application to radioautography. Stain Technol 29:225-239. doi:10.3109/10520295409115475

Assis S. 2013. Beyond the visible world:bridging macroscopic and paleohistopathological techniques in the study of periosteal new bone formation in human skeletal remains. Unpublished Ph.D thesis. University of Coimbra.

Aufderheide A, editor. 2003. The scientific study of mummies. Cambridge: Cambridge University Press.

Aufderheide A, Rodríguez-Martín C, editores. 1998. The Cambridge encyclopedia of human paleopathology. Cambridge: Cambridge University Press.

Aufderheide A. 2011. Soft tissue taphonomy:a paleopathology perspective. Int $\mathrm{J}$ Paleopathol 1:75-80. doi:10.1016/j.ijpp.2011.10.001

Baccino E, Ubelaker D, Hayek L-A, Zerilli A. 1999. Evaluation of seven methods of estimating age at death from mature human skeletal remains. J Forensic Sci 44:931936.

Barnes I, Young J, Dobney K. 2000. DNA-based identification of goose species from two archaeological sites in Lincolnshire. J Arch Sci 2:91-100. doi:10.1006/ jasc. 1999.0440

Bartelink E, Wiersema J, Demaree R. 2001. Quantitative analysis of sharp-force trauma:an application of scanning electron microscopy in forensic anthropology. J Forensic Sci 46:1288-1293.

Beasley M, Brown W, Legge A. 1992. Incremental banding in dental cementum:methods of preparation for teeth from archaeological sites and for modern comparative specimens. Int J Osteoarchaeol 2:37-50. doi:10.1002/ oa. 1390020107
Beauchesne P, Saunders S. 2006. A test of the revised Frost's 'rapid manual method' for the preparation of bone thin sections. Int J Osteoarchaeol 16:82-87. doi:10.1002/ oa. 804

Bell L, Jones S. 1991. Macroscopic and microscopic evaluation of archaeological pathological bone:backscattered electron imaging o putative pagetic bone. Int J Osteoarchaeol 1:179-184. doi:10.1002/oa.1390010307

Bell L, Piper K. 2000. An introduction to palaeohistopathology. En:Cox M, Mays S, editores. Human osteology in archaeology and forensic sciences. London:Greenwich Medical Media Ltd. p. 255-274.

Bell L, Skinner M, Jones S. 1996. The speed of postmortem change to the human skeleton and its taphonomic significance. Forensic Sci Int 82:129-140. doi:10.1016/03790738(96)01984-6

Bell L. 2012. Histotaphonomy. En: Crowder C, Stout S, editores. Bone histology: an anthropological perspective. Boca Raton: CRC Press. p 241-251.

Bellard F, Cortés J. 1991. A muscular parasite in a mummified girl. Int J Osteoarchaeol 1:215-218. doi:10.1002/ oa. 1390010313

Bello S, Soligo C. 2008. A new method for the quantitative analysis of cutmark micromorphology. J Arch Sci 35:1542-1552. doi:10.1016/j.jas.2007.10.018

Ben-Menahem A, editor. 2009. Historical encyclopedia of natural and mathematical sciences. Berlin: SpringerVerlag.

Bianucci R, Mattutino G, Lallo R, Charlier P, Jouin-Spriet H, Peluso A, Higham T, Torre C, Massa E. 2008. Immunological evidence of Plasmodium falciparum infection in an Egyptian child mummy from the Early Dynastic Period. J Arch Sci 35:1880-1885. doi:10.1016/j. jas.2007.11.019

Blondiaux J, Charlier P. 2008. Palaeocytology in skeletal remains:microscopic examination of putrefaction fluid deposits and dental calculus of skeletal remains from French archaeological sites. Int J Osteoarchaeol 18:110. doi:10.1002/oa.931

Boel L, Boldsen J, Melsen F. 2007. Double lamellae in trabecular osteons:towards a new method for age estimation by bone microscopy. Homo 58:269-277. doi:10.1016/j. jchb.2006.08.007

Boivin G, Meunier P. 1993. Histomorphometric methods applied to bone. En: Grupe G, Garland A, editores. Histology of ancient human bone: methods and diagnosis. Berlin: Springer-Verlag. p. 137-156.

Brickley M, Ives R. 2006. Skeletal manifestations of infantile scurvy. Am J Phys Anthropol 129:163-172. doi:10.1002/ajpa.20265.

Brickley M, Mays S, Ives R. 2007. An investigation of skeletal indicators of vitamin D deficiency in adults:effective markers for interpreting past living conditions and pollution levels in 18th and 19th century Birmingham, England. Am J Phys Anthropol 132:67-79. doi:10.1002/ ajpa.20491

Bromage T, Boyde A. 1984. Microscopic criteria for the determination of directionality of cutmarks on bone. Am J Phys Anthropol 65:359-366. doi:10.1002/ ajpa.1330650404

Bromage TG, Perez Ochoa A, Boyde A. 2005. Portable confocal microscopy reveals fossil hominid microstructure. Microsc Analysis 19:5-7.

Brothwell D, Sandison A, Gray P. 1969. Human biological observations on a Guanche mummy with anthracosis. Am J Phys Anthropol 30:333-347. doi:10.1002/ ajpa. 1330300303

Bullington J. 1991. Deciduous dental microwear of pre- 
historic juveniles from the lower Illinois River Va1ley. Am J Phys Anthropol 84:59-73. doi:10.1002/ ajpa.1330840106

Burke A, Castanet J. 1995. Histological observations of cementum growth in horse teeth and their application to archaeology. J Arch Sci 22:479-493. doi:10.1006/ jasc. 1995.0047

Caropreso S, Bondioli L, Capannolo D, Cerroni L, Macchiarelli R, Condo S. 2000. Thin sections for hard tissue histology: a new procedure. J Microsc 199:244247. doi:10.1046/j.1365-2818.2000.00731.x

Cattaneo C, DiMartino S, Scali S, Criag OE, Grandi M, Sokol RJ. 1999. Determining the human origin of fragments of burnt bone:a comparative study of histological, immunological, and DNA techniques. Forensic Sci Int 102:181-191. doi:10.1016/S0379-0738(99)00059-6

Cattaneo C, Porta D, Gibelli D, Gamba C. 2009. Histological determination of the human origin of bone fragments. J Forensic Sci 54:531-533. doi:10.1111/j.15564029.2009.01000.x

Chan A, Crowder C, Rogers T. 2007. Variation in cortical bone histology within the human femur and its impact on estimating age at death. Am J Phys Anthropol 132:80-88. doi:10.1002/ajpa.20465

Chandler N, Fyfe D. 1997. Root canals of buried teeth:radiographic changes due to crystal growth. Int J Osteoarchaeol 7:11-17. doi:10.1002/(SICI)10991212(199701)7:1<11::AID-OA318>3.0.CO;2-I

Charles D, Condon K, Cheverud J, Buikstra J. 1986. Cementum annulation and age determination in Homo sapiens. I Tooth variability and observer error. Am J Phys Anthropol 71:311-320. doi:10.1002/ajpa.1330710306

Cho H, Stout S, Bishop T. 2006. Cortical bone remodelling rates in a sample of African American and European American descent groups from the American Midwest:comparisons of age and sex in ribs. Am J Phys Anthropol 130:214-226. doi:10.1002/ajpa.20312

Cho H, Stout S. 2011. Age-associated bone loss and intraskeletal variability in the Imperial Romans. J Anthropol Sci 89:109-125. doi:10.4436/jass.89007

Ciranni R, Castagna M, Fornaciari G. 1999. Goiter in an eighteenth-century Sicilian mummy. Am J Phys Anthropol 108:427-432. doi:10.1002/(SICI)10968644(199904)108:4<427::AID-AJPA4>3.0.CO;2-7

Ciranni R, Fornaciari G. 2004. Juvenile cirrhosis in a 16th century Italian mummy Current technologies in pathology and ancient human tissues. Virchows Archiv 445:647-650. doi:10.1007/s00428-004-1094-1

Collins M, Nielsen-Marsh C, Hiller J, Smith C, Roberts J, Prigodich R, Wess T, Csapò J, Millard A, Turner-Walker G. 2002. The survival of organic matter in bone:a review. Archaeometry 44:383-394. doi:10.1111/14754754.t01-1-00071

Cox M, Bell L. 1999. Recovery of human skeletal elements from a recent UK murder inquiry:preservational signatures. J Forensic Sci 44:945-950. doi:10.1520/ JFS12021J

Croker S, Clement J, Donlon D. 2009. A comparison of cortical bone thickness in the femoral midshaft of humans and two non-human mammals. Homo 60:551-565. doi:10.1016/j.jchb.2009.07.003

Crowder C, Rosella L. 2007. Assessment of intra- and intercostal variation in rib histomorphometry:its impact on evidentiary examination. J Forensic Sci 52:271-276. doi:10.1111/j.1556-4029.2007.00388.x

Cuijpers A. 2006. Histological identification of bone fragments in archaeology:telling humans apart horses and cattle. Int J Osteoarchaeol 16:465-480. doi:10.1002/oa.848
Cullen TM, Evans, DC, Ryan MJ, Currie PJ, Kobayashi Y. 2014. Osteohistological variation in growth marks and osteocyte lacunar density in a theropod dinosaur (Coelurosauria:ornithomimidae). BMC Evol Biol 14:231. doi:10.1186/s12862-014-0231-y

De Boer H, Aarents M, Maat G. 2012. Staining ground sections of natural dry bone tissue for microscopy. Int J Osteoarchaeol 22:379-386. doi:10.1002/oa.1208

De Boer H, Aarents M, Maat G. 2013a. Manual for the preparation and staining of embedded natural dry bone tissue sections for microscopy. Int J Osteoarchaeol 23:8393. doi:10.1002/oa. 1242

De Boer H, Van der Merwe AE, Maat G. 2013b. The diagnostic value of microscopy in dry bone paleopathology:a review. Int J Paleopathol 3:113-121. doi:10.1016/j. ijpp.2013.03.004

De Donno A, Santoro V, Di Fazio A, Corrado S, Urso D, Baldassarra S, Di Nunno N, Introna F. 2009. Analysis of Neolithic human remains discovered in southern Italy. J Arch Sci 37:482-487. doi:10.1016/j.jas.2009.10.009

Denton J. 2008. Slices of mummy:a histologist's perspective. En: David R, editor. Egyptian mummies and modern science. Cambridge:Cambridge University Press. p. $71-82$.

Dirks W, Reid D, Jolly C, Phillips-Conroy J, Brett F. 2002. Out of the mouths of baboons:stress life history and dental development in the Awash National Park hybrid zone Ethiopia. Am J Phys Anthropol 118:239-252. doi:10.1002/ajpa.10089

Dittmann K, Grupe G, Manhart H, Peters J, Strott N. 2006. Histomorphometry of mammalian and avian compact bone. En: Grupe G, Peters J, editores. Microscopic examinations of bioarchaeological remains:keeping a close eye on ancient tissues. Leidorf:Verlag Marie Leidorf. p. 48-101.

Dittmann K. 2003. Histomorphometric analysis of primate and domesticated animal long bone microstructure. En: Grupe G, Peters J, editores. Decyphering ancient bones:the research potential of bioarchaeological collections. Leidorf: Verlag Marie Leidorf. p. 215-225.

Dore B, Pavan F, Masali M. 2001. Histological techniques and microscopic analysis of biological agents for preservation of human bone remains. Biotech Histochem 76:89-95. doi:10.1080/bih.76.2.89.95

Drapeau M, Streeter M. 2006. Modelling and remodelling responses to normal loading in the human lower limb. Am J Phys Anthropol 129:403-409. doi:10.1002/ ajpa. 20336

Drusini A. 1996. Sampling location in cortical bone histology. Am J Phys Anthropol 100:609-610. doi:10.1002/ (SICI) 1096-8644(199608)100:4<609::AIDAJPA12>3.0.CO;2-4

Emmanual J. 1988. A rapid method for producing stained sections of plastic embedded undecalcified bone sections. Stain Technol 63:329-331.

Ericksen M, Stix A. 1991. Histologic examination of age of the first African Baptist church adults. Am J Phys Anthropol 85:247-252. doi:10.1002/ajpa.1330850302

Ericksen M. 1991. Histologic estimation of age at death using the anterior cortex of the femur. Am J Phys Anthropol 84:171-179. doi:10.1002/ajpa.1330840207

Ericksen M. 1997. Comparison of two methods of estimating age at death in a Chilean Preceramic population. Int J Osteoarchaeol 7:65-70. doi:10.1002/(SICI)10991212(199701)7:1<65::AID-OA317>3.0.CO;2-2

Eshed V, Latimer B,Greenwald C, Jellema L, Rothschild B, Wish-Baratz S, Hershkovitz I. 2002. Button osteoma:its etiology and pathophysiology. Am J Phys Anthropol 118:217-230. doi:10.1002/ajpa.10087 
Estebaranz F, Martinez L, Galbany J, Turbon D, Perez-Perez A. 2009. Testing hypotheses of dietary reconstruction from buccal dental microwear in Australopithecus afarensis. J Hum Evol 57:739-750. doi:10.1016/j.jhevol.2009.07.007

Fabbri P, Lonoce N, Masieri M, Caramella D, Valentino M, Vassallo S. 2012. Partial cranial trephination by means of Hippocrates trypanon from 5th century BC Himera (Sicily Italy). Int J Osteoarchaeol 22:194-200. doi:10.1002/oa.1197.

FitzGerald C, Saunders S. 2005. Test of histological methods of determining chronology of accentuated striae in deciduous teeth. Am J Phys Anthropol 127:277-290. doi:10.1002/ajpa.10442

Fox C, Frayer D. 1997. Non-dietary marks in the anterior dentition of the Krapina Neanderthals. Int $\mathrm{J}$ Osteoarchaeol 7:133-149. doi:10.1002/(SICI)10991212(199703)7:2<133::AID-OA326>3.0.CO;2-4

Frost H. 1958. Preparation of thin undecalcified bone sections by rapid manual method. Biotech Histochem 33:273-277. doi:10.3109/10520295809111862

Frost H. 1968. Tetracycline bone labeling in anatomy. Am J Phys Anthropol 29:183-195. doi:10.1002/ ajpa.1330290212

Frost H. 1987. Secondary osteon populations:an algorithm for determining mean bone tissue age. Am J Phys Anthropol 30:221-238. doi:10.1002/ajpa.1330290212

Garland A. 1993. An introduction to the histology of exhumed mineralized tissue. En: Grupe G, Garland A, editores. Histology of ancient human bone:methods and diagnosis. Berlin:Springer-Verlag. p. 1-16.

Goldman HM, Bromage TG, Thomas D, Clement JG. 2003. Preferred collagen fiber orientation in the human midshaft femur. Anat Rec A Disciv Mol Cell Evol Biol 272:434:445. doi:10.1002/ar.a.10055

Goodman A, Rose R.1990. Assessment of systemic physiological perturbations from dental enamel hypoplasias and associated histological structures. Am J Phys Anthropol 33:59-110. doi:10.1002/ajpa.1330330506

Gordon K. 1982. A study of microwear on chimpanzee molars:implications for dental micro-wear analysis. Am J Phys Anthropol 59:195-215. doi:10.1002/ ajpa. 1330590208

Gosman J, Ketcham R. 2009. Patterns in ontogeny of human trabecular bone from Sun Watch Village in the prehistoric Ohio Valley: general features of microarchitectural change. Am J Phys Anthropol 138:318-332. doi:10.1002/ajpa.20931

Graf W. 1949. Preserved histological structures in Egyptian mummy tissues and ancient Swedish skeletons Acta Anat 8:236-250. doi:10.1159/000140412

Greenlee D, Dunnell R. 2009. Identification of fragmentary bone from the Pacific. J Arch Sci 37:957-970. doi:10.1016/j.jas.2009.11.029

Griebeler EM, Klein N, Sander PM. 2013. Aging, maturation and growth of Sauropodomorph dinosaurs as deduced from growth curves using long bone histological data:an assessment of methodological constraints and solutions. Plos One 8:e67012. doi:10.1371/journal. pone. 0067012

Grupe G, Dreses-Werringloer U. 1993. Decomposition phenomena in thin sections of excavated human bones. En: Grupe G, Garland A, editores. Histology of ancient human bone: methods and diagnosis. Berlin: SpringerVerlag. p. 27-36.

Han S-H, Kim S-H, Ahn Y-W, Huh G-Y, Kwak D-S, Park D-K, Lee U-Y, Kim Y-S. 2009. Microscopic age estimation from the anterior cortex of the femur in Korean adults. J Forensic Sci 54:519-522. doi:10.1111/j.15564029.2009.01003.x

Hanson D, Buikstra J. 1987. Histomorphological alteration in buried human bone from the lower Illinois Valley: implications for palaeodietary research. J Arch Sci 14:549-563. doi:10.1016/0305-4403(87)90038-0

Hanson M, Cain C. 2007. Examining histology to identify burned bone. J Arch Sci 34:1902-1913. doi:10.1016/j. jas.2007.01.009

Harsányi L. 1993. Differential diagnosis of human and animal bone. En: Grupe G, Garland A, editores. Histology of ancient human bone: methods and diagnosis. Berlin: Springer-Verlag. p. 79-94.

Haverkort C, Lubell D. 1999. Cutmarks on Caspian human remains:implications for Maghreb Holocene social organization and palaeoeconomy. Int $\mathrm{J}$ Osteoarchaeol 9:147-169. doi:10.1002/(SICI)10991212(199905/06)9:3<147::AID-OA466>3.0.CO;2-W

Havill L. 2003. Osteon remodelling dynamics in the Cayo Santiago Macaca mulatta: the effect of matriline. Am J Phys Anthropol 121:354-360. doi:10.1002/ajpa.10208

Haynes S, Searle J, Bretman A, Dobney K. 2002. Bone preservation and ancient DNA: the application of screening methods for predicting DNA survival. J Arch Sci 29:585-592. doi:10.1006/jasc.2001.0731

Hays J, editor. 2009.The burdens of disease:epidemics and human response in Western history. New Brunswick: Rutgers University Press.

Hedges R, Millard A, Pike A. 1995. Measurements and relationships of diagenetic alteration of bone from three archaeological sites. J Arch Sci 22:201-209. doi:10.1006/ jasc. 1995.0022

Henning C, Cooper D. 2011. Brief communication:the relation between standard error of the estimate and sample size of histomorphometric aging methods. Am J Phys Anthropol 145:658-664. doi:10.1002/ajpa.21540

Hermann P. 1986. Two examples of biogenous dead bone decomposition and their consequences for taphonomic interpretation. J Arch Sci 13:417-430. doi:10.1016/03054403(86)90012-9

Herrmann B. 1993. Light microscopy of excavated human bone. En: Grupe G, Garland A, editores. Histology of ancient human bone: methods and diagnosis. Berlin:Springer-Verlag. p. 17-26.

Hess M, Klima G, Pfaller K, Künzel K, Gaber O. 1998. Histological investigations on the Tyrolean ice man. Am J Phys Anthropol 106:521-532. doi:10.1002/(SICI)10968644(199808)106:4<521::AID-AJPA7>3.0.CO;2-L

Heuck F. 1993. Comparative histological and microradiographic investigations of human bone. En: Grupe, G; Garland, A editores. Histology of ancient human bone: methods and diagnosis. Berlin: Springer-Verlag. p. 125136.

Hildebolt C, Bate G, McKee J, Conroy G. 1986. The microstructure of dentine in taxonomic and phylogenetic studies. Am J Phys Anthropol 70:39-46. doi:10.1002/ ajpa.1330700109

Hillier M, Bell S. 2007. Differentiating human bone from animal bone: a review of histological methods. J Forensic Sci 52:249-263. doi:10.1111/j.1556-4029.2006.00368.x

Hillson S, Bond S. 1997. Relationship of enamel hypoplasia to the pattern of tooth crown growth: a discussion. Am J Phys Anthropol 104:89-103. doi:10.1002/(SICI)10968644(199709)104:1<89::AID-AJPA6>3.0.CO;2-8

Hogg J. 1854. The microscope: its history, construction and applications. London: The Illustrated London Library.

Hogue S, Melsheimer R. 2008. Integrating dental microwear and isotopic analyses to understand dietary 
change in East-central Mississippi. J Arch Sci 35:228238. doi:10.1016/j.jas.2007.03.002

Holden J, Phakey P, Clement J. 1995. Scanning electron microscope observations of incinerated human femoral bone: a case study. Forensic Sci Int 74:17-28. doi:10.1016/0379-0738(95)01734-Z

Hollund H, Jans M, Collins M, Kars H, Joosten I, Kars S. 2012. What happened here? Bone histology as a tool in decoding the postmortem histories of archaeological bone from Castricum The Netherlands. Int J Osteoarchaeol 22:537-548. doi:10.1002/oa.1273

Hoyte D. 1968. Alizarin red in the study of the apposition and resorption of bone. Am J Phys Anthropol 29:157177. doi:10.1002/ajpa.1330290210

Hutchinson D. 1996. Brief encounters: Tatham Mound and the evidence for Spanish and Native American confrontation. Int $\mathrm{J}$ Osteoarchaeol 6:51-65. doi:10.1002/(SICI)1099-1212(199601)6:1<51::AID$\mathrm{OA} 257>3.0 . \mathrm{CO} ; 2-\mathrm{E}$

Iwaniec U, Crenshaw T, Schoeninger M, Stout S, Ericksen M. 1998. Methods for improving the efficiency of estimating total osteon density in the human anterior middiaphyseal femur. Am J Phys Anthropol 107:12-24. doi:10.1002/(SICI)1096-8644(199809)107:1<13::AIDAJPA2 $>3.0 . \mathrm{CO} ; 2-\mathrm{E}$

Jans M, Nielsen-Marsh C, Smith C, Collins M, Kars H. 2004. Characterization of microbial attack on archaeological bone. J Arch Sci 31:87-95. doi:10.1016/j. jas.2003.07.007

Jans M. 2008. Microbial bioerosion of bone - a review. En: Wisshak M, Tapanila L, editores. Current developments in bioerosion. Erlangen Earth Conference Series. Berlin: Springer-Verlag. p. 397-413.

Kato L. 1973. The centenary of the discovery of the leprosy bacillus. Canad Med Assoc J 109:628-629.

Kerley E, Ubelaker D. 1978. Revisions in the microscopic method of estimating age at death in human cortical bone. Am J Phys Anthropol 49:545-546. doi:10.1002/ ajpa.1330490414

Kerley E. 1965. The microscopic determination of age in human bone. Am J Phys Anthropol 23:149-163. doi:10.1002/ajpa.1330230215

Kim M, Oh C, Lee I, Lee B, Choi J, Lim D, Yi Y, Han W, Kim Y, Bok G, Lee S. 2008. Human mummified brain from a medieval tomb with lime-soil mixture barrier of the Joseon Dynasty Korea. Int J Osteoarchaeol 18:614623. doi:10.1002/oa.962

Kim Y-S, Kim DI, Park D-K, Lee J-H, Chung N-E, Lee W-T, Hans S-H. 2007. Assessment of histomorphological features of the sterna end of the fourth rib for age estimation in Koreans. J Forensic Sci 52:1237-1242. doi:10.1111/j.1556-4029.2007.00566.x

King T, Humphrey L, Hillson S. 2005. Linear enamel hypoplasias as indicators of systemic physiological stress: evidence from two known age-at-death and sex populations from postmedieval London. Am J Phys Anthropol 128:547-559. doi:10.1002/ajpa.20232

Kuhn G, Schultz M, Müller R, Rühli F. 2007. Diagnostic value of micro-CT in comparison with histology in the qualitative assessment of historical human postcranial bone pathologies. Homo 58:97-115. doi:10.1016/j. jchb.2006.11.002

Lacruz RS, Ramirez Rozzi FV, Bromage TG. 2006. Variation in Enamel Development of South African Fossil Hominids. J Human Evol 51:580- 590. doi:10.1016/j. jhevol.2006.05.007

Lalueza C, Péréz-Péréz A, Turbón D. 1996. Dietary inferences through buccal microwear analysis of Middle and Upper Pleistocene human fossils. Am J Phys Anthropol 100:367-387. doi:10.1002/(SICI)10968644(199607)100:3<367::AID-AJPA5>3.0.CO;2-R

Lamm ET. 2007. Paleohistology widens the field of view in paleontology. Microsc Microanal 13(Suppl 2):50. doi:http://dx.doi.org/10.1017/S1431927607075368

Lee AH, O'Connor PM. 2013. Bone histology confirms determinate growth and small body size in the noasaurid theropod Masiakasaurus knopfleri. J Vert Paleont 33:865-876. doi:http://dx.doi.org/10.1080/02724634.2 013.743898

Leeuwenhoek F. 1720. Observations upon the bones and the periosteum in a letter to the Royal Society. Proceedings of the Royal Society of London Philosophical Transactions of the Royal Society (1683-1775) 31:91-97.

Lovell N. 2000. Paleopathological description and diagnosis. En: Katzenberg A, Saunders S, editores. Biological anthropology of the human skeleton. New York: WileyLiss. p. 217-248.

Lozano M, Bermudez de Castro J, Carbonell E, Arsuaga J. 2008. Non-masticatory uses of anterior teeth of Sima de los Huesos individuals (Sierra de Atapuerca Spain). J Human Evol 55:713-728. doi:10.1016/j.jhevol.2008.04.007

Luna L, Aranda C, Bosio L, Beron M. 2008. A case of multiple metastases in Late Holocene hunter-gatherers from the Argentine Pampean region. Int J Osteoarchaeol 18:492-506. doi:10.1002/oa.950

Lynne S. 1990. Paleopathology and diagenesis:an SEM evaluation of structural changes using backscattered electron imaging. J Arch Sci 17:85-102. doi:10.1016/03054403(90)90016-X

Lynnerup N, Frohlich B, Thomsen J. 2006. Assessment of age at death by microscopy:unbiased quantification of secondary osteons in femoral cross sections. Forensic Sci Int 159:s100-s103. doi:10.1016/j. forsciint.2006.02.023

Ma P, Teaford M. 2010. Diet reconstruction in Antebellum Baltimore: insights from dental microwear analysis. Am J Phys Anthropol 141:571-582. doi:10.1002/ajpa.21177

Maat G, Gerretsen R, Aarents M. 2006a. Improving the visibility of tooth cementum annulations by adjustment of the cutting angle of microscopic sections. Forensic Sci Int 159:s95-s99. doi:10.1016/j.forsciint.2006.02.038

Maat G, Maes A, Aarents M, Nagelkerke N. 2006b. Histological age prediction from the femur in a contemporary Dutch sample. J Forensic Sci 51:230-237. doi:10.1111/ j.1556-4029.2006.00062.x

Maat G, Van Den Bos R, Aarents M. 2001. Manual preparation of ground sections for the microscopy of natural bone tissue: update and modification of Frost's 'rapid manual method'. Int J Osteoarchaeol 11:366-374. doi:10.1002/oa.578

Maat G. 1991. Ultrastructure of normal and pathological fossilized red blood cells compared with pseudopathological biological structures. Int J Osteoarchaeol 1:209214. doi:10.1002/oa.1390010312

Maat G. 2004. Scurvy in adults and youngsters: the Dutch experience. A review of the history and pathology of a disregarded disease. Int J Osteoarchaeol 14:77-81. doi:10.1002/oa.708

Macadam R, Sandison T. 1969. The electron microscope in paleopathology. Medical History 13:81-85. doi:http:// dx.doi.org/10.1017/S0025727300013983

Macho G, Abel R, Schutkowski H. 200.5 Age changes in bone microstructure:do they occur uniformly? Int J Osteoarchaeol 15:421-430. doi:10.1002/oa.797

Maggiano C, Dupras T, Schultz M, Biggerstaff J. 2009. 
Confocal laser scanning microscopy: a flexible tool for simultaneous polarization and three-dimensional fluorescence imaging of archaeological compact bone. $\mathrm{J}$ Arch Sci 36:2392-2401. doi:10.1016/j.jas.2009.06.021

Mahoney P. 2006. Dental microwear from Natufian huntergatherers and early Neolithic farmers: comparisons within and between samples. Am J Phys Anthropol 130:308-319. doi:10.1002/ajpa.20311

Mahoney P. 2007. Human dental microwear from Ohalo II (22500-23500 cal BP) Southern Levant. Am J Phys Anthropol 132:489-500. doi:10.1002/ajpa.20548

Mann A, Monge J, Lampl M. 1991. Investigation into the relationship between perikymata counts and crown formation times. Am J Phys Anthropol 86:175-188. doi:10.1002/ajpa.1330860207

Marks M, Rose J. 1985. Scanning electron-microscopy of Wilson bands and enamel hypoplasias. Am J Phys Anthropol 66:202-202. doi:10.1002/ajpa.1330660203.

Martin D, Armelagos G. 1979. Morphometrics of compact bone:an example from Sudanese Nubia. Am J Phys Anthropol 51:571-577. doi:10.1002/ajpa.1330510409

Martin D, Armelagos G. 1985. Skeletal remodelling and mineralization as indicators of health: an example from prehistoric Sudanese Nubia. J Hum Evol 14:527-537. doi:10.1016/S0047-2484(85)80031-2

Martin D, Magennis A, Rose J. 1987. Cortical bone maintenance in an historic Afro-American cemetery sample from Cedar Grove Arkansas. Am J Phys Anthropol 74:255-264. doi:10.1002/ajpa.1330740212

Martin S, Guatelli-Steinberg D, Walker P. 2008. Brief communication: comparison of methods for estimating chronological age at linear enamel formation on anterior dentition. Am J Phys Anthropol 135:362-365. doi:10.1002/ajpa.20725

Martiniaková M, Grosskopf B, Omelka R, Dammers K, Vondráková M, Bauerová M. 2007. Histological study of compact bone tissue in some mammals: a method for species determination. Int $\mathrm{J}$ Osteoarchaeol 17:82-90. doi:10.1002/oa.856

Martiniaková M, Vondrakova M, Omelka R. 2006. Manual preparation of thin sections from historical human skeletal material. Timisoara Medical J 56:15-17.

Mayr E, editor. 1982. The growth of biological thought: diversity evolution and inheritance. Harvard: Harvard University Press.

Mayr E, editor. 2004. What makes biology unique? Considerations on the autonomy of a scientific discipline. Cambridge: Cambridge University Press.

Mazzarello P. 1999. A unifying concept:the history of cell theory. Nature Cell Biol 1:E13-E15. doi:10.1038/8964

Mekota A, Vermehren M. 2005. Determination of optimal rehydration fixation and staining methods for histological and immunohistochemical analysis of mummified soft tissues. Biotech Histochem 80:7-13. doi:10.1080/10520290500051146

Merrill R, editor. 2010. Introduction to epidemiology. Sudbury: Jones and Bartlett Publishers LLC.

Miles A E. 2001. Microscopic configurations on the barebone surfaces of mammalian synovial joints. Int J Osteoarchaeol 11:406-414.doi:10.1002/oa.582

Miller C, Dove S, Cottone J. 1988. Failure of use of cemental annulations in teeth to determine the age of humans. J Forensic Sci 33:137-43.

Minozzi S, Manzi G, Ricci F, di Lernia S, Borgognini Tarli S. 2003. Non-alimentary tooth use in prehistory:an example from early Holocene in Central Sahara (Uan Muhuggiag Tadrart Acacus Libya). Am J Phys Anthropol 120:225-232. doi:10.1002/ajpa.10161
Molnar S, Przybeck T, Gantt D, Elizondo R, Wilkerson J. 1981. Dentin apposition rates as markers of primate growth. Am J Phys Anthropol 55:443-453. doi:10.1002/ ajpa. 1330550405

Moodie R, editor. 1918a. Studies in paleopathology I General consideration of the evidences of pathological conditions found among fossil animals. Harvard: Harvard University.

Moodie R. 1918b. Paleontological evidences of the antiquity of disease. The Scientific Monthly 7:265-281.

Moodie R. 1921. Studies in the paleopathology of Egypt. Chicago: The University of Chicago Press.

Morris A, Rodgers A. 1989. A probable case of prehistoric kidney stone disease from the Northern Cape Province South. Africa. Am J Phys Anthropol 79:521-527. doi:10.1002/ajpa.1330790408

Mulhern D. 2000. Rib remodelling dynamics in a skeletal population from Kulubnarti Nubia. Am J Phys Anthropol 111:519-530. doi:10.1002/(SICI)10968644(200004)111:4<519::AID-AJPA7>3.0.CO;2-7

Mulhern DM, Ubelaker DH. 2001. Differences in osteon banding between human and nonhuman. J Forensic Sci. 46:220-222.

Mulhern DM, Ubelaker DH. 2003. Histologic examination of bone development in juvenile chimpanzees. Am J Phys Anthropol 122:127-133. doi:10.1002/ajpa.10294

Mulhern DM, Ubelaker DH. 2012. Differentiating human from non-human bone microstructure. En: Crowder C, Stout S, editores. Bone histology: an anthropological perspective. Boca Raton: CRC Press. p 109-134.

Nicholson R. 1998. Bone degradation in a compost heap. J Arch Sci 25:393-403. doi:10.1006/jasc.1997.0208

Nielsen-Marsh C, Hedges R. 2000. Patterns of diagenesis in bone I: the effects of site environments. J Arch Sci 27:1139-1150. doi:10.1006/jasc. 1999.0537

Nystrom P, Phillips-Conroy J, Jolly C. 2004. Dental microwear in anubis and hybrid baboons (Papio hamadryas sensu lato) living in Awash National Park Ethiopia. Am J Phys Anthropol 125:279-291. doi:10.1002/ ajpa. 10274

Oh C, Seo M, Chai J, Lee S, Kim M, Park J, Shin D. 2010. Amplification and sequencing of Trichuris trichiura ancient DNA extracted from archaeological sediments. J Arch Sci 37:1269-1273. doi:10.1016/j.jas.2009.12.029

Ortner D, editor. 2003. Identification of pathological conditions in human skeletal remains. Amsterdam: Academic Press.

Oyen O, Rice R, Samuel M. 1979. Browridge structure and function in extant primates and Neanderthals. Am J Phys Anthropol 51:83-95. doi:10.1002/ajpa.1330510111

Padian K, Ricqlès AJ, Horner JR. 2001. Dinosaurian growth rates and bird origins. Nature 412:405-408. doi: $10.1038 / 35086500$

Paral V, Witter K, Tonar Z. 2007. Microscopic examination of ground sections - a simple method for distinguishing between bone and antler. Int J Osteoarchaeol 17:627634. doi:10.1002/oa.912

Patrick M. 2006. Microwear and morphology:functional relationships between human dental microwear and the mandible. J Hum Evol 50:452-459. doi:10.1016/j.jhevol.2005.11.003

Pavón M, Cucina A, Tiesler V. 2010. New formula to estimate age at death in Maya populations using histomorphological changes in the fourth human rib. J Forensic Sci 55:473-477. doi:10.1111/j.1556-4029.2009.01265.x

Pawlicki R. 1978. Methods of preparation of fossil bone samples for light and transmission electron microscopy. Biotech Histochem 53:95-102. doi:10.3109/10520297809111449 
Pearson O, Lieberman D. 2004. The aging of Wolff's "law": ontogeny and responses to mechanical loading in cortical bone. Am J Phys Anthropol 125:63-99. doi:10.1002/ ajpa. 20155

Peck J, Stout S. 2007. Intraskeletal variability in bone mass. Am J Phys Anthropol 132:89-97. doi:10.1002/ ajpa.20464

Perry M, Newnam J, Gilliland M. 2008. Differential diagnosis of a calcified object from a 4th-5th century AD burial in Aqaba Jordan. Int J Osteoarchaeol 18:507-522. doi:10.1002/oa.960

Pfeiffer S, Pinto D. 2012. Histological analyses of human bone from archaeological contexts. En: Crowder C, Stout S, editores. Bone histology: an anthropological perspective. Boca Raton: CRC Press. p 297-311.

Pfeiffer S. 1980. Bone remodelling age estimates compared with estimates by other techniques. Curr Anthropol 21:793-794.

Pfeiffer S. 2000. Paleohistology: health and disease. En: Katzenberg A, Saunders S, editores. Biological anthropology of the human skeleton. New York: Wiley-Liss. p 287-302.

Pfeiffer S. 2006. Cortical bone is juveniles. En: Grupe G, Peters J, editores. Microscopic examinations of bioarchaeological remains: keeping a close eye on ancient tissues. Leidorf : Verlag Marie Leidorf. p. 15-28.

Pickering T, Hensley-Marschand B. 2008. Cutmarks and hominid handedness. J Arch Sci 35:310-315. doi:10.1016/j.jas.2007.03.012

Post P, Daniels F. 1969. Histological and histochemical examination of American indian scalps mummies and a shrunken head. Am J Phys Anthropol 30:269-293. doi:10.1002/ajpa.1330300212

Puech P-F, Albertini H. 1984. Dental microwear and mechanisms in early hominids from Laetoli and Hadar. Am J Phys Anthropol 65:87-91. doi:10.1002/ ajpa.1330650112

Pugh M, Savchuck W. 1958. Suggestions on the preparation of undecalcified bone for microradiography. Biotech Histochem 33:287-293. doi:10.3109/10520295809111865

Quintelier K. 2009. Calcified uterine leiomyomata from a post-medieval nunnery in Brussels Belgium. Int J Osteoarchaeol 19:436-442. doi:10.1002/oa.971

Renz H, Radlanski R. 2006. Incremental lines in root cementum of human teeth are reliable age. marker? Homo 57:29-50. doi:10.1016/j.jchb.2005.09.002

Richards GD, Jabbour RS, Horton CF, Ibarra CL, MacDowell AA. 2012. Color changes in modern and fossil teeth induced by synchrotron microtomography. Am J Phys Anthropol. 149:172-180. doi:10.1002/ajpa.22103

Roberts S, Smith C, Millard A, Collins M. 2002. The taphonomy of cooked bone: characterizing boiling and its physic-chemical effects. Archaeometry 44:485-494. doi:10.1111/1475-4754.t01-1-00080

Robling A, Stout S. 2008. Histomorphometry of human cortical bone: applications to age estimation En: Katzenberg A, Saunders S, editores. Biological anthropology of the human skeleton. New Jersey: John Wiley Sons. p. 149-171.

Roksandic M, Vlak D, Schillaci M, Voicu D. 2009. Technical note: applicability of tooth cementum annulation to an archaeological population. Am J Phys Anthropol 140:583-588. doi:10.1002/ajpa.21136

Rose J, Armelagos G, Lallo J. 1978. Histological enamel indicator of childhood stress in prehistoric skeletal samples. Am J Phys Anthropol 49:511-516. doi:10.1002/ ajpa.1330490411

Rose J. 1977. Defective enamel histology of prehistoric teeth from Illinois. Am J Phys Anthropol 46:439-446. doi:10.1002/ajpa.1330460309

Rühli F, Kuhn G, Evison R, Müller R, Schultz M. 2007. Diagnostic value of micro-CT in comparison with histology in the qualitative assessment of historical human skull bone pathologies. Am J Phys Anthropol 133:10991111. doi:10.1002/ajpa.20611

Ryan A. 1979. Wear striation direction on primate teeth:a scanning electron microscope examination. Am J Phys Anthropol 50:155-167. doi:10.1002/ajpa.1330500204

Sanchez J, Etxeberria F. 1991. Renal and biliary calculi:a palaeopathological analysis. Int J Osteoarchaeol 1:231234. doi:10.1002/oa.1390010316

Sanchez S, Ahlberg P, Trinajstic K, Mirone A, Tafforeau P. 2012. Three-dimensional synchrotron virtual paleohistology: a new insight into the world of fossil bone microstructures. Microsc Microanal 8:1095-1105. doi:http://dx.doi.org/10.1017/S1431927612001079

Sanchez S, Tafforeau P, Ahlberg PE. 2014. The humerus of Eusthenopteron: a puzzling organization presaging the establishment of tetrapod limb bone marrow. Annual Review Earth Planetary Sci 37:163-179. doi:10.1098/ rspb.2014.0299

Sander PM, Klein N, Buffetaut E, Cuny G, Suteethorn V, Le Loeuff J. 2004. Adaptive radiation in sauropod dinosaurs:bone histology indicates rapid evolution of giant body size through acceleration. Organisms, Diversity \& Evolution 4:165-173. doi:10.1016/j. ode.2003.12.002

Sandinson A. 1955. The histological examination of mummified material. Biotech Histochem 30:277-283. doi:10.3109/10520295509114479

Sandison A. 1967. Sir Marc Armand Ruffer (1859-1917) pioneer of paleopathology. Medical History 11:150-156. doi:http://dx.doi.org/10.1017/S002572730001200X

Schaffler M, Burr D. 1984. Primate cortical bone microstructure: relationship to locomotion. Am J Phys Anthropol 65:191-197. doi:10.1002/ajpa.1330650211

Schmidt C. 2001. Dental microwear evidence for a dietary shift between two nonmaize-reliant prehistoric human populations from Indiana. Am J Phys Anthropol 114:139145. doi:10.1002/1096-8644(200102)114:2<139::AIDAJPA1013>3.0.CO;2-9

Schmidt-Schultz T, Schultz M. 2007. Well preserved non-collagenous extracellular matrix proteins in ancient bone and teeth. Int J Osteoarchaeol 17:91-99. doi:10.1002/oa. 858

Schultz M. 1997. Microscopic investigation of excavated skeletal remains:a contribution to paleopathology and forensic medicine. En: Haglund W, Sorg M, editores. Forensic taphonomy:the postmortem fate of human remains. Boca Raton: CRC Press. p. 201-222.

Schultz M. 2012. Light microscopic analysis of macerated pathologically changed bones. En: Crowder C, Stout S, editores. Bone histology:an anthropological perspective. Boca Raton: CRC Press. p. 253-296.

Scott R, Ungar P, Bergstrom T, Brown C, Childs B, Teaford M, Walker A. 2006. Dental microwear texture analysis:technical considerations. J Hum Evol 51:339349. doi:10.1016/j.jhevol.2006.04.006

Šefčáková A, Strouhal E, Nemecková A, Thurzo M, Stassíková-Stukovská D. 2001. Case of metastatic carcinoma from end of the 8th-Early 9th century Slovakia. Am J Phys Anthropol 116:216-229. doi:10.1002/ ajpa. 1117

Shillito L-M, Bull I, Matthews W, Almond M, Williams J, Evershed R. 2011. Biomolecular and micromorphological analysis of suspected faecal deposits at Neo- 
lithic Catalhoyuk Turkey. J Arch Sci 38:1869-1877. doi:10.1016/j.jas.2011.03.031

Shin D, Youn M, Chang B. 2003. Histological analysis on the medieval mummy in Korea. Forensic Sci Int 137:172-182. doi:10.1016/S0379-0738(03)00335-9

Shipman P, Rose J. 1983. Evidence of butchery and hominid activities at Torralba and Ambrona:an evaluation using microscopic techniques. J Arch Sci 10:465-474. doi:10.1016/0305-4403(83)90061-4

Simmons D. 1985. Options for bone aging with the microscope. Am J Phys Anthropol 28:249-263. doi:10.1002/ ajpa.1330280514

Singh I, Gunberg D. 1970. Estimation of age at death in human males from quantitative histology of bone fragments. Am J Phys Anthropol 33:373-381. doi:10.1002/ ajpa.1330330311

Spatola B, Damann F, Ragsdale B. 2012. Bone histology collections of the National Museum of Health and Medicine. En: Crowder C, Stout S, editores. Bone histology: an anthropological perspective. Boca Raton: CRC Press. p. 313-326.

Squires K, Thompson T, Islam M, Chamberlain A. 2011. The application of histomorphometry and Fourier Transform Infrared Spectroscopy to the analysis of early Anglo-Saxon burned bone. J Arch Sci 38:23992409. doi:10.1016/j.jas.2011.04.025

Stein M, Hayashi S, Sander PM. 2013. Long bone histology and growth patterns in ankylosaurs: implications for life history and evolution. PLoS One 8:e68590. doi:10.1371/journal.pone. 0068590

Sterchi D, Eurell J. 1989. A new method for preparation of undecalcified bone sections. Stain Technol 64:201-205. doi:10.3109/10520298909107000

Stevens G, Wakely J. 1993. Diagnostic criteria for identification of seashell as a trephination implement. Int J Osteoarchaeol 3:167-176. doi:10.1002/oa.1390030303

Stout S, Crowder C. 2012. Bone remodelling, histomorphology, and histomorphometry. En: Crowder C; Stout S, editores. Bone histology:an anthropological perspective. Boca Raton: CRC Press. p. 1-21.

Stout S, Gehlert J. 1982. Effects of field size when using Kerley's histological method for determination of age at death. Am J Phys Anthropol 58:123-125. doi:10.1002/ ajpa. 1330580203

Stout S, Paine R. 1992. Histological age estimation using rib and clavicle. Am J Phys Anthropol 87:111-115. doi:10.1002/ajpa.1330870110

Stout S, Porro M, Perotti B. 1996. Brief communication: a test and correction of the clavicle method of Stout and Paine for histological age estimation of skeletal remains. Am J Phys Anthropol 100:139-142. doi:10.1002/(SICI)10968644(199605)100:1<139::AID-AJPA12>3.0.CO;2-1

Stout S, Stanley S. 1991. Percent osteonal bone versus osteon counts:the variable of choice for estimating age at death. Am J Phys Anthropol 86:515-519. doi:10.1002/ ajpa. 1330860407

Stout S, Teitelbaum S. 1976. Histological analysis of undecalcified thin sections of archeological bone. Am J Phys Anthropol 44:263-269. doi:10.1002/ajpa.1330440208

Stout S. 1978. Histological structure and its preservation in ancient bone. Curr Anthropol 19:601-604.

Streeter M. 2012. Histological age-at-death estimation. En: Crowder C, Stout S, editores. Bone histology:an anthropological perspective. Boca Raton:CRC Press. p. 135-152.

Stuart-Macadam P. 1987. Porotic hyperostosis:new evidence to support the anemia theory. Am J Phys Anthropol 74:521-526. doi:10.1002/ajpa.1330740410
Stutz A. 2002. Polarizing microscopy identification of chemical diagenesis archaeological cementum. J Arch Sci 29:1327-1347. doi:10.1006/jasc.2001.0805

Tafforeau P, Boistel R, Boller E, Bravin A, Brunet M, Chaimanee Y, Cloetens P, Feist M, Hoszowska J, Jaeger J-J, Kay RF, Lazzari V, Marivaux L, Nel A, Nemozl C, Thibault X, Vignaud P, Zabler S. 2006. Applications of $\mathrm{X}$-ray synchrotron microtomography for non-destructive $3 \mathrm{D}$ studies of paleontological specimens. Appl Phys A 83:195-202. doi:10.1007/s00339-006-3507-2

Teaford M, Lytle J. 1996. Brief communication: diet-induced changes in rates of human tooth microwear: a case study involving stone-ground maize. Am J Phys Anthropol 100:143-147. doi:10.1002/(SICI)10968644(199605)100:1<143::AID-AJPA13>3.0.CO;2-0

Teaford M, Maas M, Simons E. 1996. Dental microwear and microstructure in early oligocene primates from the Fayum Egypt:implications for diet. Am J Phys Anthropol 101:527-543. doi:10.1002/(SICI)10968644(199612)101:4<527::AID-AJPA7>3.0.CO;2-S

Teaford M, Runestad J. 1992. Dental microwear and diet in Venezuelan primates. Am J Phys Anthropol 88:347364. doi:10.1002/ajpa.1330880308

Thalhammer S, Heckl W, Zink A, Nerlich A. 2001. Atomic force microscopy for high resolution imaging of collagen fibrils - a new technique to investigate collagen structure in historic bone tissues. J Arch Sci 28:10611068. doi:10.1006/jasc. 2000.0644

Tucker B, Hutchinson D, Gilliland M, Charles T, Daniel H, Wolfe L. 2001. Microscopic characteristics of hacking trauma. J Forensic Sci 46:234-240.

Turner P, Holtom D. 1981. The use of a fabric softener in the reconstitution of mummified tissue prior to paraffin wax sectioning for light microscopical examination. Biotech Histochem 56:35-38. doi:10.3109/10520298109067272

Turner-Walker G, Jans M. 2008. Reconstructing taphonomic histories using histological analysis. Palaeogeogr Palaeoclimatol Palaeoecol 266:227-235. doi:10.1016/j. palaeo.2008.03.024

Turner-Walker G, Mays S. 2008. Histological studies on ancient bones. En:Pinhasi R, Mays S, editores. Advances in human paleopathology. Chichester:John Wiley \& Sons Ltd. p. 121-146.

Turner-Walker G. 2008. The chemical and microbial degradation of bones and teeth. En: Pinhasi R, Mays $\mathrm{S}$, editores. Advances in human paleopathology. Chichester:John Wiley \& Sons Ltd. p. 3-29.

Ubelaker DH. 1998. The evolving role of the microscope in Forensic Anthropology. En: Reichs KJ, editor. Forensic osteology: advances in the identification of human remains. Springfield: Charles C. Thomas. P. 514-532.

Ungar P, Grine F, Teaford M, El Zaatari S. 2006. Dental microwear and diets of African early Homo. J Hum Evol 50:78-95. doi:10.1016/j.jhevol.2005.08.007

Ungar P, Spencer M. 1999. Incisor microwear diet and tooth use in three Amerindian populations. Am J Phys Anthropol 109:387-396. doi:10.1002/(SICI)10968644(199907)109:3<387::AID-AJPA7>3.0.CO;2-F

Van der Merwe A, Maat G, Steyn M. 2010. Ossified haematomas and infectious bone changes on the anterior tibia: histomorphological features as an aid for accurate diagnosis. Int J Osteoarchaeol 20:227-239. doi:10.1002/ oa. 1026

Villa C, Lynnerup N. 2010. Technical note:a stereological analysis of the cross-sectional variability of the femoral osteon population. Am J Phys Anthropol 142:491-496. doi:10.1002/ajpa.21269 
Von Hunnius, T.; Roberts, C.; Boylston, A.; Saunders, S. 2006. Histological identification of syphilis in pre-Columbian England. Am J Phys Anthropol 129:559-566. doi:10.1002/ajpa.20335

Wakely J, Manchester K, Roberts C. 1991. Scanning electron microscopy of rib lesions. Int J Osteoarchaeol 1:185-189. doi:10.1002/oa.1390010308

Walker R, Parsche F, Bierbrier M, McKerrow J. 1987. Tissue identification and histologic study of six lung specimens from Egyptian mummies. Am J Phys Anthropol 72:43-48. doi:10.1002/ajpa.1330720106

Wallin J, Tkocz I, Kristensen G. 1994. Microscopic age determination of human skeletons including an unknown but calculable variable. Int J Osteoarchaeol 4:353-362. doi:10.1002/oa.1390040409

Wapler U, Crubézy E, Schultz M. 2004. Is cribra orbitalia synonymous with anemia? Analysis and interpretation of cranial pathology in Sudan. Am J Phys Anthropol 123:333-339. doi:10.1002/ajpa.10321

Weinstein R, Simmons D, Lovejoy C. 1981. Ancient bone disease in a Peruvian mummy revealed by quantitative skeletal histomorphometry. Am J Phys Anthropol 54:321-326. doi:10.1002/ajpa.1330540304

Wendy D. 1998. Histological reconstruction of dental development and age at death in a juvenile gibbon $(\mathrm{Hy}$ - lobates lar). J Hum Evol 35:411-425. doi:10.1006/ jhev.1997.0185

Weston D. 2009. Brief communication: paleohistopathological analysis of pathology museum specimens:can periosteal reaction microstructure explain lesion etiology? Am J Phys Anthropol 140:186-193. doi:10.1002/ajpa.21081

White T. 1986. Cut marks on the Bodo cranium: a case of prehistoric defleshing. Am J Phys Anthropol 69:503509. doi:10.1002/ajpa.1330690410

Wilson C, editor. 1995. The invisible world: early modern philosophy and the invention of the microscope. Princeton: Princeton University Press.

Wittwer-Backofen U, Gampe J, Vaupel J. 2004. Tooth cementum annulation for age estimation:results from a large known-age validation study. Am J Phys Anthropol 123:119-129. doi:10.1002/ajpa.10303

Witzel C, Kierdorf U, Schultz M, Kierdorf H. 2008. Insights from the inside:histological analysis of abnormal enamel microstructure associated with hypoplastic enamel defects in human teeth. Am J Phys Anthropol 136:400414. doi:10.1002/ajpa.20822

Woodruff L, Norris W. 1955. Sectioning of undecalcified bone with special reference to radioautographic applications. Stain Technol 30:179-188. doi:10.3109/10520295509114462 